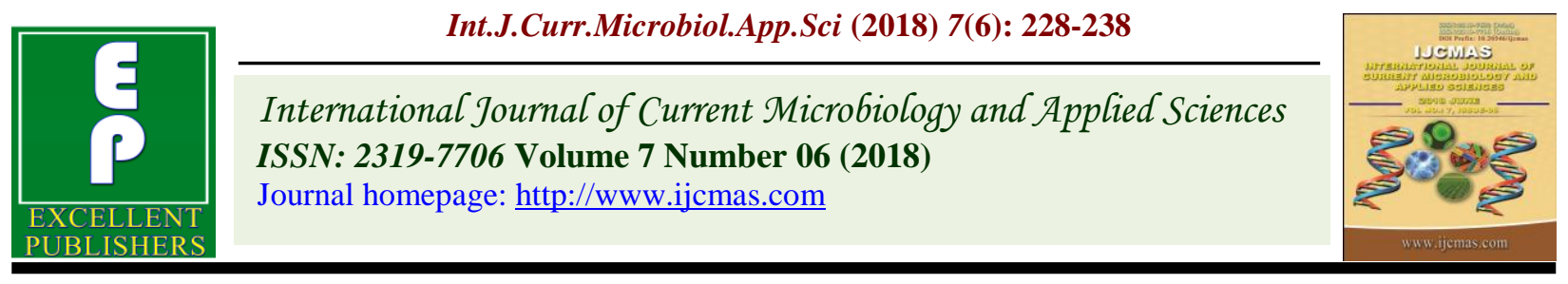

Review Article

https://doi.org/10.20546/ijcmas.2018.706.028

\title{
Protective Cultures - A Review
}

\author{
Amareswari Dokka*, Y.kotilinga Reddy, G.S.Spoorthy and I.Sankara Reddy
}
Department of Dairy Technology, College of Dairy Technology, Sri Venkateswara Veterinary University, Tirupati-517502, A.P., India

*Corresponding author

\begin{tabular}{|l|}
\hline Ke y w o r d s \\
Protective Cultures, \\
shelf-life of food \\
products, \\
food matrix
\end{tabular}

A B S T R A C T
Addition of cultures to meals is an innovative multi disciplinary from the fields of food microbiology. Protective cultures are considered as food safety factor with the improving the microbiological safety of food. They are selected from either from conventional starter cultures, from traditionally fermented foods or newly isolated stains groups with GRAS. These are food grade bacteria, inhibiting undesirable microorganisms through the production of low molecular mass compounds help in deliver the desired body and texture, flavour profile and health benefits. Protective cultures may have particular importance when used in non-fermented foods with a neutral $\mathrm{pH}$ value and high water activity $\left(\mathrm{a}_{\mathrm{w}}>0.96\right)$ that are subject to an increased hygiene risk The control of spoilage yeast and moulds are traditionally done by chemical additives, but the application of antifungal protective cultures is very promosing and used in dairy industries. The effectiveness of some bacteriocinogenic protective cultures has been studied in several food systems and these are available in freeze dried form.

\section{Introduction}

Protective cultures are preparations consisting of live microorganisms (pure cultures or culture concentrates) that are added to foods with the aim of reducing risks by pathogenic or toxigenic microorganisms. The discovery that certain strains amongst the fermentation organisms are noticeably competitive, and in particular that they can also inhibit pathogenic and toxigenic microorganisms in foods, opens up the possibility that these properties can be used for extended application in foods in general. The term 'bio protection' was coined for such applications (Bech Hansen, 2002). The cultures used are called 'protective cultures. They develop their protective effect via metabolic pathways in food, although they do not usually determine the typical nature of a fermented food characterised by the starter 
culture. The protective cultures available in practice in fact contain the same microorganisms as found in the starter cultures. Their implementation should support good manufacturing practices, thereby reducing risks of growth and survival of pathogens and spoilage organisms. In addition, under abuse conditions of temperature, handling, etc., their metabolic activities (e.g. acid or gas production) may serve as an indicator of microbial risk.

Desirable properties of protective cultures: (Holzapfel et al., 1995)

No health risks

No production of toxins

No biogenic amines or other metabolites detrimental to health

Non pathogenic

Bring about beneficial effects in product

Adaptation to product/substrate

Reliability of consistent protective activity

Predictability of metabolic activity under given set of parameters (e.g. lactic acid production/ no gas)

Competitiveness against autochthonous organisms

Specific enzymatic activities, e.g. for meat

Nitrate reductase

Catalase

No negative (sensory) effects on product under GMP (e.g. non production of acid, gas, slime, etc., depending on product type)
Function as 'indicator' under abuse conditions

\section{Protective culture approach}

Biological preservation refers to the extension of the shelf-life of food products and improvement of their microbial safety by using two different approaches:

The inoculation of the food matrix with target microorganisms, defined as protective cultures, with consequent in situ production of inhibitory molecules and/or a competitive effect against pathogen and spoilage bacteria.

The use of microbial metabolites in purified form, in particular bacteriocins.

The use of microorganisms as protective cultures may have several advantages, as microorganisms can not only be the source of anti-microbial peptides but also of a wide spectrum of molecules, such as organic acids, carbon dioxide, ethanol, hydrogen peroxide and diacetyl, whose antimicrobial action is well known. Competition of protective cultures with potential pathogens, is another way to restrict the growth of undesired organisms. Moreover, these microorganisms may have additional functional properties and, in some circumstances, they can be beneficial for the consumers. Last but not least, they can contribute to the flavour, texture and nutritional value of the product. Therefore, the concept of "protective cultures" is a broad one and it is not strictly related to the production of bacteriocins.

\section{Role of LAB as protective culture}

Lactic acid bacteria (LAB) produce a variety of antifungal compounds, the synergistic action of which prevent the growth of a broad range of fungi and can be used as protective culture for improving microbiological safety of food products without changing their 
sensory characteristics (Florou-Paneri et al., 2013). LAB occur naturally in different food sources and have been used for centuries in food fermentation and became a part of human diet without any adverse health effects which procured them the 'GRAS' (generally recognized as safe) status. The long tradition of using LAB in food and feed substantiated with recent scientific understanding on its antifungal efficacy and enhanced health effects suggest them as perfect alternatives to chemical preservatives (Divya et al., 2012).

LAB have been reported to produce wide range of fungal growth inhibiting substances such as organic acids including hydroxyl fatty acids, low molecular weight bioactive compounds and proteinaceous compounds. Selected LAB strains (as in fermentation) or the bioactives purified from the culture medium can be exploited as efficient alternatives for food preservation. Oranusi et al., (2013) reported the antifungal activity of Lactococcuslactis against various Aspergillus, Penicillium, Mucor and Rhizopus. Growth inhibitory action of Lactobacillus, Enterococcus and Leuconostoc cultures were reported against varying fungal groups such as Debaryomyces hansenii, Saccharomyces cerevisiae and Penicillium sp. LAB are inhibitory to many fungal pathogens and at the same time they coexist with various yeast strains during fermentations.

\section{Principles behind the effectiveness of protective cultures}

Competitive exclusion, for example through competition for nutrients and/or binding sites on the substrate, or through better adaptation to the oxygen content.

Formation of antagonistically active substances, e.g. with organic acids (e. g. lactic, acetic, propionic, formic, benzoic acid), ethanol, $\mathrm{H}_{2} \mathrm{O}_{2}, \mathrm{CO}_{2}$, bacteriocins (ribosomal synthesized peptides, proteins and polypeptide compounds such as Nisin), as well as antibiotics or other antagonistically active principles with antimycotic or antibacterial activity.

Such principles may be equally allocated to the spectrum of methods that are in general use in the food industry (e.g. drying, salting, cooling, freezing, oxygen removal, acidification, chemical preservation). Protective cultures may have particular importance when used in non-fermented foods with a neutral $\mathrm{pH}$ value and high water activity $\left(a_{w}>0.96\right)$ that are subject to an increased hygiene risk.

\section{Inhibitory metabolites of protective cultures}

The major mechanisms that contribute to the preservative effect of protective cultures are considered below:

\section{Bacteriocin production by protective cultures}

Protective cultures (PCs), which are antagonistic towards targeted FPSOs (food poisoning or spoilage organisms), are used in the controlled micro flora applications. Bacteriocins (low molecular weight proteins produced by certain species of lactic acid bacteria), on the other hand, are effective at low concentration. The growth and bacteriocin production of the $\mathrm{PCs}$, nisin - producing Lactococcus lactis and pediocin A -producing $P$. pentosaceus, at refrigeration temperatures. Lactococcus and Pediococcus spp. are inhibitory to a range of FPSOs including $L$. monocytogenes, Staphylococcus aureus, $C$. perfringens and Bacillus stearothermophilus.

One reason for the inability of a protective culture to suppress Listeria in refrigerated foods is the slow growth rate of the 
bacteriocin-producing strain at low temperatures. The strain needs time to grow to a high cell density to produce bacteriocins and acids and is not able to prevent initial growth of the pathogen. When the protective culture is used in combination with nisin, the Listeria population is kept at a low level by nisin activity for several days and during this time the bacteriocin-producing culture can reach sufficiently high numbers to suppress those organisms that escaped nisin action.

PC, protective cultures. FPSO, food poisoning or spoilage organism. Adapted from Rodgers et al., (2002).

\section{Antifungal protective cultures on the global market: (Frank Grattepanche et al., 2008)}

A few antifungal protective cultures are commercialized and their applications are still emerging, especially for dairy products but also for other foods and feeds

\section{Protective cultures}

\section{Cheese}

Recently, antifungal cultures have gained importance for cheese applications although limited work has been done in this field (Schnürer and Magnusson, 2005). The assessment of cheese spoilage by yeasts and moulds is complicated because fungal activity during ripening can be either needed or detrimental to product quality, depending on the type of cheese and microorganisms (Fleet. 1990). Spoilage of cheese due to fungal growth is caused by the production of volatile compounds, leading to off-flavours, and also mycotoxin accumulation, which may promote allergies. Penicillium spp. and Aspergillus spp. are important spoilage moulds in preservativefree hard, semi-hard and semi-soft cheeses, whereas Candida spp., Kluyveromyces marxianus and Pichia spp. are main contaminants in unripened soft cheeses (Filtenborg et al., 1996).

\section{Raw unsalted meat}

Bacterial pathogens of most significance to the consumer of raw meat (salmonellae, Campylobacter, enterohemorrhagic E. coli, Y. enterocolitica) are gram-negative. Likewise, raw meat stored aerobically under chilled conditions is spoiled by Gram-negative bacteria, predominantly pseudomonas. Growth potential of Gram-negatives in such meats may be reduced by lactic and acetic acids formed by LAB.

\section{Foods of plant origin}

Protective cultures show some potential for the bio preservation of foods of plant origin such as fresh and minimally processed refrigerated vegetables and salads often stored under modified atmosphere packaging delicatessen salads, and fermented vegetables. LAB used as protective cultures should show no or only moderate growth at low temperatures and should not affect the sensory properties of the refrigerated delicatessen salad. Upon temperature increase, they should start to grow rapidly and to acidify the product. At the same time, growth of pathogenic bacteria should be suppressed by the protective cultures. Model studies with potato and meat salads showed that an increase in temperature from $6^{\circ} \mathrm{C}$ to $23^{\circ} \mathrm{C}$ resulted in a rapid multiplication of the inoculated LAB used as protective cultures, whereas numbers of $\mathrm{E}$. coli, $\mathrm{Cl}$. sporogenes, and $S$. saprophyticus decreased rapidly.

\section{Propionic acid bacteria as protective cultures in fermented milks}

The shelf life of fermented milks was prolonged by initial levels of $2 \times 10^{7}$ cells of both L. Rhamnosus LC70S and $P$. 
freudenreichii $\mathrm{ssp}$. shermanii $\mathrm{JS} \cdot \mathrm{g}^{-1}$ product. The cell numbers of L. rhamnosusLC70S and $P$. freudenreichii ssp. shermanii did not increase during the storage of fermented milks at 6 "C for 4 weeks, but the protective strains continued to metabolize as the concentrations of diacetyl and acetic acid in quark and the concentrations of diacetyl, propionic and acetic acids in yogurt increased during storage. In a production scale test of quark, the protective culture at a level of $2 \times 10^{7}$ cells/g: inhibited the growth of molds. The sensory quality of this product was superior to the control product due to the production of diacetyl from citrate by the protective culture. The protective culture did not interfere with the basic starters in yogurt as the cell counts of S. thermophiles and L. bulgaricus were similar in both the control yogurt and in the yogurt manufactured with the protective culture (Tarja et al., 1999).

\section{Cooked meat products}

Contamination of cooked meat products with Listeria monocytogenes poses a constant threat to the meat industry. Cooked, sliced, vacuum- or gas-packaged ham and servelat sausage from nine meat factories in Norway were inoculated with $10 \mathrm{cfu} / \mathrm{g}$ of a mixture of three rifampicin resistant (rif-mutant) strains of L. monocytogenes and stored at $8^{\circ} \mathrm{C}$ for four weeks.

Growth of L. monocytogenes and indigenous lactic acid flora was followed throughout the storage period. LAB were isolated from samples where L. monocytogenes failed to grow. Five different strains growing well at $3^{\circ} \mathrm{C}, \mathrm{pH} 6.2$, with $3 \% \mathrm{NaCl}$, and producing moderate amounts of acid were selected for challenge experiments with the rif-resistant strains of L. monocytogenes, a nalidixic acid / streptomycin sulphate-resistant strain of Escherichia coli $0157: \mathrm{H} 7$ and a mixture of three rif-resistant strains of Yersinia enterocolitica O:3. All five LAB strains inhibited growth of both $L$. monocytogenes and E. coli O157: H7. No inhibition of $Y$. enterocolitica O: 3 was observed. A professional taste panel evaluated cooked, sliced, vacuum-packaged ham inoculated with each of the five test strains after storage for 21 days at $8^{\circ} \mathrm{C}$. All samples had acceptable sensory properties. The five LAB strains hybridised to a 23S rRNA oligonucleotide probe specific for Lactobacillus sakei. These indigenous LAB may be used as protective cultures to inhibit growth of L. monocytogenes and E. coli O157: $\mathrm{H} 7$ in cooked meat products (Sylvia Bredholt et al., 1999).

\section{Applications}

Application of a protective culture for antimicrobial protection of food should be considered only as an additional measure to good manufacturing, processing, and storage and distribution practices. Its eventual use will be determined by a number of factors, amongst which its ('food-grade') safety, and adaptation and suitability for a specific food system are the most important ones. The effectiveness of some bacteriocinogenic protective cultures has been studied in several food systems. Live PCs also do not affect

Taste and can be added to a wide range of cold products. In non-fermented products, the cultures do not grow under low temperature storage conditions. Sensory evaluation of the effect of PCs added at the level of $1-2 \mathrm{~g} / \mathrm{kg}$ to seafood chowder, vegetable curry and chicken casserole demonstrated that the panel was unable to distinguish between products with and without the cultures. Live PCs, on the other hand, offer a unique temperature responsive mechanism bacteriocins are produced only when the product is exposed to elevated temperatures. 
Metabolic products of lactic acid bacteria with antimicrobial properties

\begin{tabular}{l} 
Product \\
Organic acids \\
lactic acid \\
acetic acid \\
\hline Hydrogen peroxide \\
Enrymes \\
lactoperoxidase system with H,O, \\
lysozyme (by recomb. DNA-technology) \\
\hline Low-molecular metabolites \\
reuterin (3-OH-propionaldehyde) \\
diacetyl \\
fatty acids \\
Bacteriocins \\
nisin \\
other
\end{tabular}

\section{Main target organisms}

Putrefactive and Gram-negative bacteria, some fungi

Putrefactive bacteria, clostridia, some yeasts and fungi

Pathogens and spoilage organisms, especially in protein-rich foods

Pathogens and spoilage bacteria (milk and dairy products)

Undesired Gram-positive bacteria

Wide spectrum of bacteria, moulds and yeasts

Gram-negative bacteria

Different bacteria

Some LAB and Gram-positive bacteria, notably endospore-formers Gram-positive bacteria, inhibitory spectrum according to producer strain and bacteriocin type

Food systems in which effectiveness of bacteriocinogenic protective cultures against Listeria monocytogenes was tested

\begin{tabular}{|l|l|}
\hline Food system & Protective culture \\
\hline Fresh meat & Pediococcus acidilactici PAC 1.0 \\
\hline comminuted, cured raw pork & Lactobacillus sake Lb 706 \\
\hline minimally heat-treated beef & Lactobacillus bulgricus MN \\
\hline
\end{tabular}

Inhibition of pathogens in cook-chill meals with PCs

\begin{tabular}{|c|c|c|c|c|}
\hline $\begin{array}{l}\text { Food } \\
\text { products }\end{array}$ & $\begin{array}{l}\text { Target } \\
\text { microorganisms } \\
\text { (pathogens or } \\
\text { spoilage) }\end{array}$ & $\begin{array}{l}\text { Protective } \quad \text { culture } \\
\text { employed }\end{array}$ & $\begin{array}{l}\text { Temperature } \\
\left({ }^{\circ} \mathbf{C}\right)\end{array}$ & $\begin{array}{l}\text { Inoculum } \\
\text { (cfu/g) }\end{array}$ \\
\hline Chicken meat & $\begin{array}{l}\text { S. enteriditis } \\
\text { L. monocytogenes } \\
\text { C. botulinum } \\
\text { C. perfringens } \\
\text { B. thermosphacta }\end{array}$ & $\begin{array}{l}\text { E. faecium PCD71 } \\
\text { L. fermentum ACA-DC } 179\end{array}$ & $3^{\circ} \mathrm{C}$ & $10^{4}, 10^{7}$ \\
\hline $\begin{array}{l}\text { Ready-to-eat } \\
\text { vegetables }\end{array}$ & $\begin{array}{l}\text { L. monocytogenes } \\
\text { Salmonella } \\
\text { typhimurium } \\
\text { S. aureus } \\
\text { Aeromonas hydrophila }\end{array}$ & Pediococcusspp. & $4,8^{\circ} \mathrm{C}$ & $10^{8}$ \\
\hline $\begin{array}{l}\text { Cold-smoked } \\
\text { salmon }\end{array}$ & $\begin{array}{l}\text { L. monocytogenes } \\
\text { L. innocua }\end{array}$ & L. lactis ssp. Lactis & 10 & $3 \times 10^{6}$ \\
\hline Milk & Pseudomonas frag & L.delbrueckii ssp. bulgaricus & 5,7 & $10^{8}$ \\
\hline
\end{tabular}


Antifungal protective cultures on the global market: (Frank Grattepanche et al., 2008)

\begin{tabular}{|c|c|c|c|c|c|}
\hline $\begin{array}{l}\text { Protective } \\
\text { culture }\end{array}$ & Composition & \begin{tabular}{|l} 
Activity \\
spectrum
\end{tabular} & Compounds & $\begin{array}{l}\text { Recommended } \\
\text { application }\end{array}$ & Reference \\
\hline $\begin{array}{l}\text { HOLDBACTM } \\
\text { YM-B }\end{array}$ & $\begin{array}{l}\text { Propionibacterium } \\
\text { freudenreichii subsp. } \\
\text { Shermanii JS } \\
\text { Lactobacillus } \\
\text { rhamnosusLC705 }\end{array}$ & $\begin{array}{l}\text { Yeasts, } \\
\text { moulds } \\
\text { Rhodotorula } \\
\text { rubra } \\
\text { Pichia } \\
\text { quliermondii } \\
\text { Bacillus spp }\end{array}$ & $\begin{array}{l}\text { Propionic acid } \\
\text { Acetic acid } \\
\text { Diacetyl } \\
\text { 2-Pyrrolidone-5- } \\
\text { caboxylic acid }\end{array}$ & $\begin{array}{l}\text { Yoghurt } \\
\text { Sour cream } \\
\text { Fresh cheese }\end{array}$ & $\begin{array}{l}\text { Danisco } \\
\mathrm{A} / \mathrm{S} \\
\text { (Denmark) }\end{array}$ \\
\hline $\begin{array}{l}\text { HOLDBACTM } \\
\text { YM-C }\end{array}$ & $\begin{array}{l}\text { Propionibacterium } \\
\text { freudenreichii } \\
\text { subsp. shermaniiJS } \\
\text { Lactobacillus } \\
\text { paracaseiSM20 }\end{array}$ & $\begin{array}{l}\text { Yeasts, } \\
\text { moulds } \\
\text { Candida spp. } \\
\text { Rhodotorula } \\
\text { mucilaginosa }\end{array}$ & $\begin{array}{l}\text { Propionic acid } \\
\text { Acetic acid } \\
\text { Succinic acid } \\
\text { 2-Pyrrolidone-5- } \\
\text { carboxylic acid } \\
\text { 3-Phenyllactic acid } \\
\text { Hydroxphenyllactic } \\
\text { acid }\end{array}$ & $\begin{array}{l}\text { Yoghurt } \\
\text { Sour cream } \\
\text { Fresh cheese }\end{array}$ & $\begin{array}{l}\text { Danisco } \\
\text { A/S } \\
\text { (Denmark }\end{array}$ \\
\hline $\begin{array}{l}\text { FeedtechSilage } \\
\text { F3000 }\end{array}$ & $\begin{array}{l}\text { Lactobacillus } \\
\text { plantarumMilab } 393 \\
\text { Pediococcus } \\
\text { acidilactici } \\
\text { Enterococcus faecium } \\
\text { Lactococcuslactis }\end{array}$ & $\begin{array}{l}\text { Yeasts, } \\
\text { moulds } \\
\text { Clostridium } \\
\text { spp. }\end{array}$ & $\begin{array}{l}\text { 3-Phenyllactic acid } \\
\text { Cyclic dipeptides } \\
\text { Nisin }\end{array}$ & Silage & $\begin{array}{l}\text { DeLaval } \\
\text { (Sweden) }\end{array}$ \\
\hline
\end{tabular}

\section{Potential application of protective cultures in different food systems}

\begin{tabular}{l} 
Products \\
Milk and dairy products \\
Hould-ripened cheese \\
Hard and semi-hard cheeses \\
Fresh cheese types (quarg, etc.) \\
Yoghurt (especially with added fruit, nuts and \\
cereals) \\
Meat, fish and poultry \\
Soft-type raw sausage (e.g. Mettwurst) \\
Mould-ripened fermented sausage \\
Pre-packaged fish and lightly preserved foods such as \\
cold-smoked fish, brined shrimps \\
Fresh meat \\
Self service packages of processed meat products \\
Poultry \\
\hline Vegetable type products \\
Fermented products (general) \\
Fermented products:- \\
cucumbers \\
sauerkraut \\
\hline Delicatessen and novel type foods \\
Different delicatessen type foods (refrigerated) \\
Novel type foods \\
'sous vides' \\
other cooked-chilled foods and ready-to-eat products \\
\hline
\end{tabular}

\section{Target organism}

Listeria monocytogenes

Clostridia causing late-blowing

Moulds and yeasts

Yeasts and moulds

Staphylococcus aureus, Listeria monocytogenes Staphylococcus aureus

Clostridium botulinum types E. B and F, Listeria monocytogenes, Pseudomonas, Salmonellae, Enteropathogenic, E. Coli, Listeria monocytogenes, Salmonella spp., Campylobacter spp.

Yeasts, moulds

Gas producing LAB Slime producers (e.g. leuconostocs) Producers of off-flavours and of biogenic amines

Heterofermentative LAB

Staphylococcus aureus

Yeasts

Psychrotolerant Clostridia Listeria, Bacillus determined by (novel) ecological parameters 
Commercially available products based on LAB protective cultures (Varsha and Nampoothiri, 2016)

\begin{tabular}{|l|l|l|}
\hline Protective culture & Field of application & Producer \\
\hline FreshQ & Fermented dairy products & Chr.Hansen (Denmark) \\
\hline SafeProImPorous & Meat products & Chr.Hansen (Denmark) \\
\hline Bactoferm & Meat starter culture & Chr.Hansen (Denmark) \\
\hline HOLDBAC & Fermented foods and cheese & Dupont (USA) \\
\hline Lyofast & $\begin{array}{l}\text { Fermented milk products and } \\
\text { cheese }\end{array}$ & Sacco (Italy) \\
\hline Dairy Safe & Cheese manufacture & CSK (Netherlands) \\
\hline
\end{tabular}

Examples of the genetic optimisation of protective cultures

\section{Desired trait}

\section{Expression of Lysozyme}

gene in Lactococci

Expression of lysostaphin

gene in Lactobacillus casei

Expression of phage

resistance genes

\section{Result}

Amplification of antagonism

against clostridia and

Gram-positive bacteria

Increased inhibition of

Staphylococci

Increased phage

resistance/process safety

\section{Reference}

Van de Guchte et al., (1992)

Gaier et al., (1992)

Harrington and Hill (1991
Unlike physical methods of preservation, the application of PCs does not require special equipment. An automatic dispensing device, which can be incorporated into a pump during packaging, can ensure the correct concentrations of PCs.

The most practical way of PC delivery is in a freeze-dried form; freeze-drying does not affect the growth and bacteriocin production When PCs are used for preservation, the correct inoculums and its viability become production parameters and should be treated as critical limits in HACCP programs.

Operators using PCs would face two major practical limitations:

That a culture cannot survive in hot products

Possible spoilage of the product during chilled storage.
Encapsulation of PCs in protective liposome coating or a packaging device with a culture release mechanism can minimize the impact of heat during preparation.

\section{Processes can be re-engineered}

Hot-filling in sousvide processing can be replaced with chilling the product in the kettle and then packaging it in the cold state under aseptic/hygienic conditions. The second issue of spoilage is more difficult to control. If a product is exposed to elevated temperatures (7-10 $\left.{ }^{\circ} \mathrm{C}\right)$, slow fermentation can affect the product sensory attributes. The use of PCs in sous vide products with heat-sensitive ingredients may reduce harshness of processing and the thermal damage during cooking. This improves organoleptic quality and the nutritional value (less vitamin degradation). Often, sous vide products are frozen for food safety reasons e soups 
supplied by the True Soups (Kent, Washington, USA), for example. In the future, such products can be re-designed from being frozen to chilled "PC-protected".

\section{Commercial applications of protective cultures}

\section{Microgard}

It is the pasteurised product of the fermentation of skim milk by Propionibacterium freudenreichii spp. shermanii and its protective action has been associated with diacetyl, propionic, acetic and lactic acid and probably due to a heat stable peptide with a M. mass about $700 \mathrm{~g} / \mathrm{mol}$.

It inhibits gram - negative bacteria as well as yeast and moulds but not gram positive bacteria. Micro GARD products are used for a wide range of food applications including cottage cheese, yogurt, sour cream, dairy desserts, sauces, dressings, pasta, baked goods, and prepared meals.

Inhibited yeasts and preserved commercial yoghurts for over $5^{\circ} \mathrm{C}$. The same yoghurt samples were also protected from spoilage by gram negative bacteria. There also indicate an evident shelf extension up to 6-9 days for commercially produced cottage cheese.

\section{Bioprofit}

It contains Lactobacillus rhamnosus LC705 and Propionibacterium freudenreichii spp. shermanii. Used as protective cultures $\left(10^{7}\right.$ cells per gram) the product is reported to inhibit yeasts, moulds in dairy products

\section{Limitations and future prospects of protective cultures}

The protective cultures may be applied within certain limits, indicated above with relation to food systems, as additional safety factor. These limitations concern three main features of LAB and other bacterial cultures, (Holzapfel et al., 1995):

Adaptation

Relative to product group

Persistence and competition

Sensitivity to processing parameters

Metabolic activity

Essential in a food system (risk of inactivation)

Possible deleterious sensory effects

Specific antibacterial factors such as bacteriocins

Activity spectrum

Inactivation (e.g. by product specific proteases)

Limited diffusion in solid matrix

No influence on Gram-negative bacteria

Inducible resistance

Unspecific binding to food ingredients (e.g. inactivation by lipids).

Recent advances and increased knowledge on the physiology and molecular biology of the $\mathrm{LAB}$, in addition to progresses in selection and culture techniques, give reason for optimism towards the development of improved, tailor-made protective cultures.

The main research activities will probably be directed towards the following achievements: 
Improved and targeted selection and screening methods

Optimisation ('tailoring') by recombinant DNA technology

Transfer of bacteriocin genes within the LAB; construction of multibacteriocinogenic strains

Transfer of resistance genes

Development of high potential multiple strain cultures

The protective cultures can be added to high risk products, with seafood, for example, or those which are sent to outside customers. Another possible benefit which can be derived from PCs is the reduction of the intensity of cooking. The application of antibotulinum PCs can replace the six decimal reduction of non-proteolytic $C$. botulinum with six decimal reduction of $L$. monocytogenes, both options being described by the Reference Code for an Extended Shelflife Cook-chill System (1998). This would preserve the quality of heat-sensitive ingredients, such as leafy vegetables, chicken and seafood, etc. The increase in storage temperature is another potential benefit of the application, although it would require through validation studies. The ability of the selected PCs to produce bacteriocins at low temperatures at the concentrations, which can be inhibitory to a range of FPSOs, was demonstrated. The increase in the inoculum level resulted in faster bacteriocin production. Bacteriocin detection was associated with populations reaching high levels -108-109 $\mathrm{cfu} / \mathrm{mL}$ Freeze-dried PCs can be used in commercial applications. They offer convenience, inhibitory qualities compatible with the performance of fresh PCs and are unnoticeable by consumers. The bio preservation with PCs, is important in large scale settings where extended shelf-life food service systems are used. This has to be verified with challenge studies based on complex experimental protocols. The potential spoilage at elevated temperatures and the heat sensitivity of live bacteria are the main obstacles in the commercialization of this "natural" preservation technique. Both applications of live cultures can lead to better nutrition: improvement of immunity and gut health with probiotics and the availability of a wider range of safe minimally processed meals with PC.

\section{References}

Bech Hansen, E. (2002), 'Commercial bacterial starter cultures for fermented foods of the future'. Intern. J. Food Microbiol. 78, pp. 119 -131.

Divya, J. B., Varsha, K. K., and Nampoothiri, K. M. (2012). Newly isolated lactic acid bacteria with probiotic features for potential application in food industry. Applied Biochemistry and Biotechnology, 167, 1314-1324.

Filtenborg O.J., Frisvad C., and Thrane U., (1996). Moulds in food spoilage, Int. J. Food Microbiol. 33 (1996), 85-102.

Fleet G.H., (1990). Yeasts in dairy products, J. Appl. Bacteriol. 68 (1990) 199-211.

Florou-Paneri, P., Christaki, E., and Bonos, E. (2013). Lactic acid bacteria as source of functional ingredients. INTECH Open Access Publisher.

Franck Grattepanche, Susanne MiescherSchwenninger, Leo Meile, and Christophe Lacroix, (2008): Recent developments in cheese cultures with protective and probiotic functionalities, Dairy Sci. Technol. 88, 421-444

Gaier, W., Vogel, R.F. and Hammes, W.P. (1992). Cloning and expression of the lysostaphin gene in Bacillus subtilis and Lactobacillus casei. Lett. Appl. Microbial. 14, 72-76. 
Geisen. R, and W.H. Holzapfel (1996) Genetically modified starter and protective cultures, International Journal of Food Microbiology 30, 315-324

Harrington, A. and Hill, C. (1991) Confirmation of a bacteriophageresistant derivative of Lactococcusla\&ssubsplactis425A by lysing the conjugal plasmid pNP 40 . Appl. Environ. Microbial. 57, 3405 3409.

Holzapfel, W.H. U. Schillinger, R. Gelsen, and F.-K. Lücke (2003) Starter and protective cultures, Food Preservatives Kluwer Academic/Plenum Publishers, New York

Microbial food cultures (2010), SKLM Commission Secretariat Food Chemistry and Toxicology Deutsche Forschungsgemeinschaft Kennedyallee 40: 53175

Oranusi, S., Wesley, B., and Oguoma, O. I. (2013). Antifungal properties of lactic acid bacteria LAB isolated from Ricinus communis, Pentaclethramacrophylla and Yoghurts. Global Advanced Research Journal of Food Science and Technology, 21, 01-06.

Rodgers, S., K. Kailasapathy, J. Cox and P. Peiris (2002). Bacteriocin production by protective cultures Blackwell Science Ltd Food Service Technology, 2, pp. $59-68$
Schnürer J., and Magnusson J., (2005). Antifungal lactic acid bacteria as biopreservatives, Trends Food Sci. Technol. 16 (2005) 70-78.

Svetlana Rodgers, (2008) Novel applications of live bacteria in food services: Probiotics and protective cultures, Trends in Food Science \& Technology 188-197

Sylvia Bredholta, Truls Nesbakkenb, and Askild Holcka, (1999) Protective cultures inhibit growth of Listeria monocytogenes and Escherichia coli O157:H7 in cooked, sliced, vacuumand gas packaged meat, International Journal of Food Microbiology 53 4352.

Tarja H. Suomalainen, Annika M. and MâyrâMâkinen, (1999). Propionic acid bacteria as protective cultures in fermented milks and breads, Lait 79, 165-174.

Van de Guchte, M., Van der Wal, F.M., Kok, J. and Venema, G. (1992) Lysozyme expression in Lactococcus luctis. Appl. Microbial. Biotechnol. 37, 216-224

Varsha K K, and K M Nampoothiri (2016): appraisal of lactic acid bacteria as protective cultures, Food Control 6961 64.

\section{How to cite this article:}

Amareswari Dokka, Y.kotilinga Reddy, G.S.Spoorthy and Sankara Reddy, I. 2018. Protective Cultures - A Review. Int.J.Curr.Microbiol.App.Sci. 7(06): 228-238. doi: https://doi.org/10.20546/ijcmas.2018.706.028 